\title{
Városok és régiók a 21. század elején. Nemzetközi tudományos konferencia
}

\section{Cities and regions at the beginning of the 21st century. An international conference}

\author{
ÁRVAI ANETT
}

\begin{abstract}
ÁRVAI Anett: PhD-hallgató, Eötvös Loránd Tudományegyetem, Regionális Tudományi Tanszék; 1117 Budapest, Pázmány P. sétány 1/c.; arvaianett@caesar.elte.hu
\end{abstract}

Anett ÁRVAI: PhD student, Department for Regional Science, Eötvös Loránd University; Pázmány P. sétány 1/c., H-1117 Budapest, Hungary; arvaianett@caesar.elte.hu

2016. október 5-én nemzetközi tudományos konferenciát rendeztek Győrben az MTA KRTK Regionális Kutatások Intézete Nyugat-magyarországi Tudományos Osztály (NYUTO) alapításának 30. évfordulója tiszteletére, Városok és régiók a 21. század elején címmel. A rendezvény a jeles évforduló megünneplésén túl áttekintette azokat a témaköröket, melyeket a Nyugat-magyarországi Tudományos Osztály tudományos tevékenysége érint, a hazai szakembereken túl neves külföldi vendégek előadásaival is gazdagítva a nap programját.

A konferencia ünnepélyes megnyitóval és köszöntőkkel kezdődött, ahol felszólaltak a győri kutatóintézet létrejöttében és tevékenységében segédkező személyek, szervezetek, intézmények képviselői. Ezután következtek a konferencia plenáris előadásai, majd a rendezvényt szakmai panelbeszélgetések zárták.

Az osztály az 1984-ben megalakult MTA Regionális Kutatások Központja új, vidéki kutatóintézet-hálózatának egyik első tagjaként jött létre 1986-ban, az MTA, illetve Győr és Győr-Moson-Sopron megye együttmüködésének eredményeként. Azóta a többszöri szervezeti átalakulás, intézetbezárások és névváltozás ellenére is fennmaradt és eredményesen működik a győri kutatóhely (www.rkk.hu/hu/nyuti/). Az osztály, ahogyan Lamm Vanda, az MTA Gazdaságés Jogtudományok Osztályának osztályelnök-helyettese is kiemelte nyitóbeszédében, fennállásának 30 éve során komoly elméleti kutatási eredményeket ért el, melyet jelentős publikációs tevékenysége és rendezvényei is alátámasztanak.

A nyitóbeszédekben több felszólaló is megjegyezte, az, hogy akadémiai kutatóintézet működik Győrben, komoly lehetőséget jelent a térség számára. Mind Győr, mind Győr-Moson-Sopron megye önkormányzatának képviselője

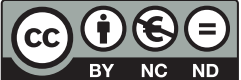


kihangsúlyozta, hogy a városnak, illetve a megyének nagy haszna származik abból, hogy a Magyar Tudományos Akadémia egyik tudományos műhelye már harminc éve a városban található, hiszen a kezdetek óta jelentős az együttmüködés a NYUTO és az önkormányzatok között. Ez nemcsak a helyi tudományos élet felpezsdülésével járt együtt, de a gyümölcsöző kapcsolat eredményeként olyan kutatási eredmények születtek, melyek segítették az önkormányzatok munkáját, a város és a megye fejlődését, versenyképességük javítását. A győri Széchenyi István Egyetemmel is szoros együttműködésben áll az osztály (a rendezvénynek is az egyetem biztosított helyszínt), mely kooperáció nagyban hozzájárult az egyetem regionális tudományi képzésének megteremtéséhez is.

Megköszönve azon kutatók munkáját, akik hivatalosan nem tagjai az osztálynak, de sokat tettek annak működéséért, átadták a „Tiszteletbeli és örökös kutatónk" elismeréseket, melyet a kerek évforduló alkalmából alapítottak. A díjat Szirmai Viktória, az MTA RKK NYUTI Közép-dunántúli Osztályának egykori osztályvezetője, Csapó Tamás, aki az MTA RKK NYUTI szombathelyi osztályvezetője volt, illetve a nemrég elhunyt Tóth Károly, a Fórum Kisebbségkutató Intézet alapítója és első igazgatója kapta (www.rkk.hu; ttmk.nyme.hu; felvidek.ma).

A plenáris előadások három téma köré szerveződtek, megjelenítve az osztály egy-egy hangsúlyos kutatási területét: A Duna-térség, Közép-Európa fejlesztési és területi integrációs kérdései; Városfejlödés és -fejlesztés smart eszközökkel; A vidék átalakulása Közép-Európában. Mindegyik témakörben két előadás hangzott el, egy-egy neves külföldi eladó és a NYUTO egy-egy munkatársa mutatta be kutatási eredményeit, ennek a rendezési elvnek köszönhetően a helyben folyó kutatások nemzetközi aspektusaira is jó rálátás nyílt.

Az első témakörben a határon átnyúló együttműködésekről, a térségi identitásról és a Duna régió kihívásairól és lehetőségeiről volt szó, mely a város Duna-parti és határközeli fekvése miatt Győrben fontos kutatási terület. A külföldi előadó Erhard Busek, az Institut für Donauraum und Mitteleuropa vezérigazgatója, korábbi osztrák alkancellár, illetve tudomány- és oktatásügyi miniszter volt, akinek megítélése szerint a folyó a kapcsolatot jelenti Közép-Európa különböző régiói között. Arról beszélt, milyen kihívásokkal kell szembenézni a Duna-menti területeken, és a kooperáció milyen témakörökben lehet szükséges. Előadásában ilyen együttműködési területként jelölte meg többek között a vízminőség, a demográfiai problémák, illetve a közlekedés (például hidak építése) kérdéskörét. Hardi Tamás előadásában azt a kérdést járta körbe, hogy a különböző közép-európai országok egyetemistáinak körében mennyire van jelen, illetve mennyire erős a közép-európai identitás, illetve hol húzódhat Közép-Európa határa a régió lakóinak mentális térképzetében.

A plenáris előadások második előadáspárja a „smart city” („okos város”) témakörét járta körbe, melyet nyitóbeszédében Fekete Dávid, Győr alpolgármestere is fontos együttmüködési pontként jelölt meg az osztály és a város között. A napjainkban egyre kiszélesedő kutatási területtel kapcsolatban Manfred Schrenk, a Consulting Research Projects igazgatója, illetve Lados Mihály (NYUTO) és 
Pongrácz Ferenc (IBM) adott elő. Manfred Schrenk áttekintette az okos város témakörében felmerülő különböző megközelítéseket, közös pontként megjelölve a smart fejlesztések jelentős adatigényét. Rávilágított, hogy az okos város napjainkban igencsak népszerü kutatási terület, így jelenleg majdnem minden fejlesztésre ezt a kifejezést használják, ami szintén hozzájárul a kifejezés sokféle értelmezéséhez. Lados Mihály és Pongrácz Ferenc előadásában csatlakozott ez utóbbi gondolathoz, miközben a hazai okosváros-kutatások történetét és a fogalom definiálási kérdéseit foglalták össze röviden. Véleményük szerint a magyar városok esetében a smart eszközökben történő gondolkozás még nem igazán alakult ki, amit azzal magyaráznak, hogy az ITS-ek a közelmúltban még nem ennek a szellemében íródtak.

Az utolsó kettő plenáris előadás a rurális térségek átalakulásával foglalkozott. Antonín Vaishar, a brnoi Mendel Egyetem oktatója a visegrádi országok vidéki területeinek gazdasági szerkezetátalakulásáról beszélt, kiemelve az ipar kiemelkedő szerepét. Szörényiné Kukorelli Irén prezentációjában a magyar falvakban megfigyelhető területi innovációkkal foglalkozott. Rávilágított, hogy a területi innovációkat társadalmi innovációnak kell megelőznie, mely felkészíti a lakosokat az újítások befogadására, illetve kiemelte a helyi tradíciókban gyökerező innováció (traditiovation) fontosságát.

Az ebédszünet után panelbeszélgetések következtek három, az MTA KRTK RKI részvételével zajlott vagy jelenleg is zajló OTKA (NKFIH)-kutatás témakörében. A beszélgetések nagyban követték a délelőtti előadások tematikáját. Az első blokk, melynek moderátora Hajdú Zoltán, az MTA KRTK RKI Dunántúli Tudományos Osztályának munkatársa volt, a „Duna, határ, Közép-Európa” címet viselte, melynek keretében a határon átnyúló együttműködésekről és a Duna Régió Stratégiával kapcsolatban mondták el a véleményüket a kérdéskör kutatói. A beszélgetés rávilágított arra, hogy a „Duna régió” amiatt lehet egy hosszú távon jól használható koncepció, mert értéksemleges térkategória. Emellett a határon átnyúló együttműködések problémáiról is szó esett, többek között az aszimmetrikus határon átnyúló kapcsolatokról és a bürokratikus akadályokról.

A következő beszélgetés címe „Város-állam-városfejlesztés?”, moderátora Timár Judit, az MTA KRTK RKI Alföldi Tudományos Osztályának munkatársa volt, ahol az országos szinten végbemenő strukturális változásokra adott helyi válaszokkal kapcsolatban folyt az eszmecsere. A beszélgetőpartnerek azon hatások között, melyekhez hazai városainknak alkalmazkodniuk kell, megjegyezték többek között a neoliberális mechanizmus és a tőkebefektetésekért folyó városversenyből eredő térhasználati konfliktusok, az állami centralizáció és a fejlesztési források egyre centralizáltabb elosztása, valamint a városokon belüli térbeli egyenlőtlenségek hatásait. Itt is felmerült a helyi fejlesztések azon problémája, melyet Szörényiné Kukorelli Irén a rurális innovációval kapcsolatban már a plenáris előadások során megemlített: a helyi fejlesztések gyakran egykét emberhez kötődnek, és ha ezek a kulcsszereplők eltűnnek, nagyon valószínű a térség visszaesése. 
Az utolsó panelbeszélgetés témája a Vidéki térségek átalakulása, moderátora Kovács Katalin, az MTA KRTK RKI Közép- és Észak-magyarországi Tudományos Osztályának osztályvezetője volt. A beszélgetésben részt vevő kutatók eredményei alapján ma nemcsak polarizáció, hanem szegmentáció figyelhető meg, tehát az egyes térségtípusok közötti átjárhatóság is egyre inkább megszűnik. A „leszakadó vidék" mellett, ahol a vidéki lakosság körülbelül 20-30\%-a lakik, megjelenik egyes nem szuburbán területeken is a rurális dzsentrifikáció. A kutatók szerint a társadalmi küldetéstudattal rendelkező helyi vállalkozói réteg és a szakképzett munkaerő hiánya is nagy problémát jelent ezeken a területeken, míg a vidéki középosztályt gyakran a külföldi munkavállalás menti meg a lecsúszástól.

A konferencián felvonultatott témakörök több, eltérő tématerületet öleltek fel, három fő kérdéskörre fókuszálva - határon átnyúló együttműködések, városok, rurális térségek -, tükrözve az MTA KRTK RKI NYUTO kutatásainak sokszínűségét. A rendezvény amellett, hogy érzékeltette a győri kutatóintézet eredményes múltját, a bemutatott kutatásokkal azt is elővetítette, hogy hasonlóan eredményes jövő áll a Nyugat-dunántúli Tudományos Osztály előtt. A konferencián elhangzottak alapján e reményeket azzal kívánják beváltani, hogy olyan korszerű kutatási kérdésekkel foglalkoznak, melyek a helyi kontextusban is nagy jelentőséggel bírnak, az elméleti tudományos eredmények a helyi intézményekkel folytatott partneri kapcsolatnak köszönhetően a gyakorlatban is hasznosulhatnak, így segítve a régió fejlődését, míg a kutatói utánpótlást az egyetemen folyó képzés biztosítja.

\section{Irodalom}

http://felvidek.ma/2016/09/elhunyt-toth-karoly/ (Letöltés: 2016. december 29.)

http://www.rkk.hu/hu/nyuti/ (Letöltés: 2016. december 29.)

http://www.rkk.hu/hu/cvs/szirmai_viktoria.html (Letöltés: 2016. december 29.)

http://ttmk.nyme.hu/Munkatarsak/Oneletrajzok/csapo_tamas.pdf (Letöltés: 2016. december 29.) 